Trikonomika

Volume 19, No. 2, December 2020, Page. 76-80

ISSN 1411-514X (print) / ISSN 2355-7737 (online)

\title{
DETERMINANTS OF FINANCIAL PERFORMANCE ON THE GO PUBLIC COMPANY ON BEI
}

\author{
Atang Hermawan ${ }^{1}$ \\ hermawan.atang65@gmail.com \\ Nagian Toni ${ }^{2}$ \\ Universitas Pasundan ${ }^{1}$ \\ Jl. Tamansari No.6-8, Bandung 40116 \\ Universitas Prima Indonesia ${ }^{2}$ \\ Jl. Sekip Jl. Sikambing No.simpang, Medan, Sumatera Utara 20111
}

received: 8/10/20; revised: 29/10/20; approved: 14/12/20

\begin{abstract}
The objective of this research is to get an understanding on the effect of the investment decision, capital structure and dividend policy on financial performance using the Multiple Regression Analysis. It is expected that this model will give more comprehensive analysis on the effect of the investment decision, capital structure and dividend policy on financial performance of public companies, which includes the direct or indirect effect on one variable against the others variables. on public companies in Indonesian Stock Exchange in 2014-2017. The findings reveal that, the investment decision has a more dominant effect on financial performance. The investment decision, capital structure and dividend policy have a positive effect on financial performance. The theoretical finding on this research can be developed to make investment decisions, capital structures and dividend policies of public companies. In other words, the three variables will have some means of effect on financial performance, compare with other factors.
\end{abstract}

Keywords: investment decision; capital structure; dividend policy and financial performance

\section{INTRODUCTION}

The company is one form of corporation that runs every type of business, is permanent, continuous and works within the territory of the Republic of Indonesia, for the purpose of obtaining profits and or profits (Article 1 letter b of Law number 3 of 1982 concerning Obligatory to Register of Companies). Many new companies have sprung up so as to make business competition so tight and competitive. Therefore, corporate actors are demanded to be able to manage their resources more effectively and efficiently in order to support what has been the company's goals before. Investment Decision and Dividend Policy Companies listed on the IDX have fluctuated and some companies do not distribute dividends due to declining income, for the capital structure of some companies the composition of long-term debt is greater than their own capital and some companies show their own capital is greater than their long-term debt. The size of companies in companies listed on the IDX varies with big, medium and small categories. The development of changes in share prices in sectors listed on the IDX partially decreased and some experienced increases and decreases as well as decreases and increases. According to Brigham and Houston, an increase in debt is interpreted by outsiders about the company's ability to pay obligations in the future or the presence of low business risk, this will be positively responded by the market. In much of his formal analysis, the economic theorist at least has tended to side-step the essence of this cost-of-capital problem by proceeding as though physical assets-like bonds-could be regarded as yielding known, sure streams. (Holmes, 1929). Given There are two views regarding funding decisions. The first view is known as the traditional view which states that the capital structure affects the value of the company. Another policy regarding company value is investment decisions, where investment decisions in this case are short-term and long-term investments. According to Hidayat (2019), investment decisions are an important factor in the company's financial function, where the value of the company is solely determined by investment decisions. One factor that influences financial performance is capital structure. (Hidayat, Wahyudi, Muharam, Shaferi, \& Puspitasari, 2019) The capital structure of an enterprise consists of long-term debt and shareholder's equity, where stockholder equity 
consists of preferred stock and common equity, and common equity itself is composed of Fahmi's common stock and retained earnings (2011). Referring to the description in the background and the identification of the problem above, the problem is formulated as follows:

(1) How is the condition investation decision capital structure and dividend policy of the company went public listed on the Stock Exchange; (2) What are the conditions on the financial performance of companies went public listed on the Stock Exchange; (3) How big is the influence of investment decisions on financial performance in companies going public listed on the Indonesia Stock Exchange; (4) How big is the influence of capital structure on financial performance in the company went public listed on the Stock Exchange; (5) How much influence the dividend policy on the financial performance of the Company went public listed on the Stock Exchange.

According to Nahdiroh (2013), investment decisions are provisions made by the company in spending its funds in the form of certain assets in the hope of earning profits in the future. While the Capital Structure is a balance between long-term debt with own capital. Bambang Riyanto (2010: 193) states that capital structure must be distinguished from finance companies. Capital structure is very closely related to the dividend policy of Martono and Harjito (2013), dividend policy is a policy of whether profits obtained by the company at the end of the year will be distributed to shareholders or retained to increase capital for future business development.(Press \& Review, 2009).

The Bird in the Hand Theory (Gordon and Lintner, 1963), this theory states that dividends are better than capital gains, because the dividends distributed are smaller at risk. Therefore, the company makes a high dividend payout ratio by offering a high dividend yield so that it can maximize its share price so that it impacts on the company's financial performance. Financial performance is a formal effort carried out by the company to evaluate the efficiency and effectiveness of the company's activities that have been carried out in a certain period of time. According to Irham (2011: 11), financial performance is an analysis conducted to see the extent to which a company has carried out using the rules of financial implementation properly and correctly.

Investment decisions are closely related to capital structure based on the results of research by Franklin and Muthusamy conducting research on the impact of funding decisions (capital structure) on corporate investment decisions. (S \& Muthusamy, 2011). The study concluded that financial leverage has a positive effect on investment levels. While based on the results of research Ardestani the relationship between investment decisions and dividend policy has a positive and significant impact. (Ardestani, Rasid,
Basiruddin, \& Mehri, 2013). Investment decisions are also very influential on financial performance based on research conducted by Murniati (2019) stating that investment decisions have a positive and significant effect on financial performance. Dewi and Suardana (2015) in their research found that investment decisions affect company value through financial performance. The structure of assets and firm size has a positive and significant influence on capital structure, while profitability has a negative and significant influence on capital structure. Meanwhile, two other variables, the rate of growth and business risk does not significantly influence capital structure.(Indrajaya \& Setiadi, 2011) Corporate funding decisions regarding decisions about the form and composition of funding that will be used by the company (Husnan, 2015). A significant positive relationship between leverage and investment, while we found a negative relationship between leverage investment for medium firms and positive relationship between leverage and investment in large firms. (S \& Muthusamy, 2011). Found that there was a significant negative relationship between capital structure and firm performance in low-performance firms. According to Rozeff in Rahmadhana and Yendrawati (2012: 2536), dividends contain information or as a sign of the company's prospects. If the company increases dividend payments, it can be interpreted by investors as a signal of management's expectations about the company's improved performance in the future. Many studies examining the effect of financial performance on firm value include Ervinta and Zaroni (2013) which state that the better financial performance will be reflected in the size of EVA.

Positive EVA value means that company management has succeeded in maximizing company value and the company's financial performance has increased. The improved financial performance will be in line with the increase in the company's profit. The greater the company's profits, the dividends that will be distributed to shareholders also tend to increase.

\section{METHOD}

This research uses causal quantitative research. This research uses descriptive research and verification research using a quantitative approach. Descriptive research is a type of research that aims to provide a more detailed picture of certain symptoms or phenomena. Verification research is a type of research that aims to test a theory or the results of previous research, in order to obtain results that strengthen or invalidate the theory or results of previous research. This study aimed to determine the effect of investment decisions, capital structure, and dividend policy on financial performance using the Multiple Regression Analysis. This model is expected to produce a more comprehensive analysis of the impact of investment decisions measured by 
market to book assets ratio, capital structure measured by debt to assets ratio, and dividend policy measured by dividend yield on financial performance measured by basic earning power of public company in Indonesia. Besides wanting to know the implications of financial performance on the value of the company in going public companies on the Indonesia Stock Exchange in 2014-2017. By using a target population of 513 companies and a sample of 315 companies going public on the Indonesia Stock Exchange.

\section{RESULTS AND DISCUSSION}

Based on the results of research that has been done, it shows that the samples in this study were taken from populations that were not normally distributed. In this study, the results of the normality test ignored because the number of samples (data observation) was more than 100 (Table 1). The multicollinearity test results showed that there was no multicollinearity between the independent variables in the regression model (Table 2). The result of the heteroscedasticity test shows that there is a heteroscedasticity problem in the regression model (Figure 1). The final test result is the autocorrelation test, which shows a positive autocorrelation (Table 3).

The results found that investment decisions, dividend policy, and capital structure significantly influence financial performance both simultaneously and partially (Tables 4 and 5). Investment decision, capital structure, and dividend policy impact on financial performance amounted by $43 \%$ and $57 \%$ determined by other variables (Table 6).

The results showed that investment decisions have effect on financial performance by a positive $34.46 \%$. These results are supportive and consistent with the opinions expressed by Sincar et al (2000) and Dewi \& Suardana (2015).

The effect of capital structure variables on financial performance was $4.25 \%$. This conclusion supports Myers (1977), Modigliani \& Miller (1963), De Angelo \& Masulis (1980), Masulis (1980), Bradley et al (1984), and Park \& Evan (1996). This study also supports previous research by Peersen and Rajan (1994) which says that there is a positive and significant relationship between profitability and debt ratios and companies can use more debt to improve their financial performance because the ability of debt causes managers to increase productivity to avoid bankruptcy.(PETERSEN \& RAJAN, 1994).

The effect of the dividend policy variable on financial performance was $4.26 \%$. The results of this study support Pettit (1972) and Rozeff (1982), that an increase in dividend payments is interpreted as management's belief that the company's prospects and financial performance will improve. If the company increases the payment of dividends, it is interpreted as a signal of management's expectations about the company's improved performance in the future. While Pramastuti (2007), if management decides to distribute dividends, he must have confidence that his company will have good profitability in the future. From an investor's perspective, one important indicator to assess the company's prospects in the future is to look at the dividends paid.

Partial Test Results Investment Decision on Financial Performance for the coefficients Investment Decision on Financial Performance of 0.018, the value of $t$ arithmetic amounted to 24.892 by taking a significance level $\alpha$ of $5 \%$, then the value of $t$ table is 1.972 , so that due $t$ count $=24.892$ bigger than $t$ table $=1.972$, then $\mathrm{H} 0$ is rejected or in other words the investment decisions affect the financial performance with the path coefficient of 0.018 so that any increase in the investment decision will improve the financial performance of 0.018 .

Based on the calculation, for the coefficient Dividend Policy on Financial Performance of 0.397, obtained by value $t$ arithmetic amounted to 8.345 by taking a significance level $\alpha$ of $5 \%$, then the value of $t$ table is 1.972 , so because $t$ count $=8.345$ more greater than $\mathrm{t}$ table $=1.972$, then $\mathrm{H} 0$ is rejected or, in other words dividend policy effect on financial performance with the coefficient of 0.397 so that any increase dividend policy will improve the financial performance of 0.397 .

Based on the calculation, for the capital structure coefficient on Financial Performance of 0.105, the calculated $t$ value of 6.396 is obtained by taking a significance level of $\alpha$ of $5 \%$, then the value of t table is 1.972 , so that due to $t$ arithmetic $=6.396$ more greater than $\mathrm{t}$ table $=1.972$, then $\mathrm{H} 0$ is rejected or in other words, capital structure affect the financial performance with the path coefficient of 0.105 so that any increase in capital structure will improve the financial performance of 0.105 .

\section{CONCLUSION}

Investment decisions, has an influence on the financial performance of the company went public listed on the Stock Exchange amounted to $34.46 \%$. The better the investment decision, the better the financial performance of going public companies listed on the IDX. The capital structure has an influence on the financial performance of the company went public listed on the Stock Exchange amounted to $4.25 \%$. The better the capital structure, the better the financial performance of going public companies listed on the IDX. A good capital structure is a balanced composition of debt and equity. Dividend policy has an influence on the financial performance of the company went public listed on the Stock Exchange amounted to $4.26 \%$. The better the investment policy, the better the financial performance of going public companies listed on the IDX. Referring 
to the results of the research and the usefulness of the results of this study, it is recommended to consider factors that apply good corporate governance (GCG) by publicly traded companies to decisions on financial performance and corporate value. In addition, it is also necessary to study whether the economic crisis and normal conditions provide the same conclusions. Future studies can use other indicators that make up the latent variables of investment decisions, capital structure, dividend policy and financial performance

\section{REFERENCES}

Ardestani, H. S., Rasid, S. Z. A., Basiruddin, R., \& Mehri, M. 2013. Dividend Payout Policy, Investment Opportunity Set and Corporate Financing in the Industrial Products Sector of Malasya. Journal of Applied Finance \& Banking, 3(1), 123-136. Retrieved from http://www.scienpress.com/Upload/ JAFB/Vol 3 1_8.pdf

Hidayat, R., Wāhyudi, S., Muharam, H., Shaferi, I., \& Puspitasari, I. 2019. The improve level of firm value with liquidity, debt policy and investment in indonesian emerging market. Espacios, 40(40).

Holmes, A. H. 1929. Addison's anaemia. British Medical Journal, 2(3594), 952-953. https://doi. org/10.1136/bmj.2.3594.952

Indrajaya, G., \& Setiadi, R. 2011. Pengaruh Struktur Aktiva, Ukuran Perusahaan, Tingkat Pertumbuhan,
Profitabilitas dan Risiko Bisnis Terhadap Struktur Modal: Studi Empiris Pada Perusahaan Sektor Pertambangan yang Listing di Bursa Efek Indonesia Periode 2004-2007. Maksi, 6(2).

Modigliani, F \& Miller, M. H..,1958. The cost of Capital, Corporation Finance and The Theory of Investment, The American Economic Review, 13(3), pp 261-297.

Mahmoudi, A, Ali R. Y, Hamid R. R. J. A, Kambiz B. 2013. The relationship between Capital Structure and Firm Performance. Interdisciplinary Journal of Contemporary Research in Business, Vol. 5 (8), pp:421-433.

Martono and Harjito. 2013. Financial management. Third Edition. Publisher: Ekonisia. Yogyakarta.

Nadhiroh, U. 2013. Studi Empiris Keputusan-Keputusan Dividen, Investasi, dan Pendanaan Eksternal pada Perusahaan-Perusahaan Indonesia yang Go Public di Bursa Efek Indonesia.Jurnal Otonomi, 13(1): h: 91-104.

Petersen, M. A., \& Rajan, R. G. 1994. The Benefits of Lending Relationships: Evidence from Small Business Data. The Journal of Finance, 49(1), 3-37. https://doi.org/10.1111/j.1540-6261.1994.tb04418.x

Press, T. M. I. T., \& Review, T. 2009. Dividends, Eearnings, and Stock Prices, 41(2), 99-105.

S, F. J., \& Muthusamy, K. 2011. Impact of Leverage on Firms Investment Decision. International Journal of Scientific \& Engineering Research, 2(4), 1-16.

Table 1 . Test of Normality

\begin{tabular}{lcccccc}
\hline & \multicolumn{3}{c}{ Kolmogorov-Smirnov $^{\mathrm{a}}$} & \multicolumn{3}{c}{ Shapiro-Wilk } \\
\cline { 2 - 7 } & Statistic & $\mathrm{df}$ & Sig. & Statistic & $\mathrm{df}$ & Sig. \\
\hline BEP & .200 & 1260 & .000 & .388 & 1260 & .000 \\
Market to Book Assets Ratio & .356 & 1260 & .000 & .240 & 1260 & .000 \\
Dividend Yield & .399 & 1260 & .000 & .244 & 1260 & .000 \\
DAR & .049 & 1260 & .000 & .810 & 1260 & .000 \\
\hline
\end{tabular}

Table 2. Test of Multicollinearity (Dependent Variable: BEP)

\begin{tabular}{llcc}
\hline \multirow{2}{*}{ Model } & & \multicolumn{2}{c}{ Collinearity Statistics } \\
\cline { 3 - 4 } & & Tolerance & VIF \\
\hline & (Constant) & \\
& Market to Book Assets Ratio & .905 & 1.105 \\
& DAR & .916 & 1.092 \\
& Dividend Yield & .985 & 1.015 \\
\hline
\end{tabular}

Table 3. Test of Autocorrelation

\begin{tabular}{ccccccc}
\hline $\mathrm{K}$ & $\mathrm{N}$ & $\mathrm{dL}$ & $\mathrm{dU}$ & 4-dU & 4-dL & $\mathrm{DW}$ \\
\hline 3 & 1260 & 1.90382 & 1.91023 & 2.08977 & 2.09618 & 1.177 \\
\hline
\end{tabular}


Table 4. f-Test

\begin{tabular}{lllllll}
\hline Model & & Sum of Squares & df & Mean Square & F & Sig. \\
\hline 1 & Regression & 17.838 & 3 & 5.946 & 315.583 & $.000 \mathrm{~b}$ \\
& Residual & 23.665 & 1256 & .019 & & \\
& Total & 41.503 & 1259 & & & \\
\hline
\end{tabular}

a. Dependent Variable: BEP

b. Predictors: (Constant), Dividend Yield, DAR, Market to Book Assets Ratio

Table 5. Coefficients and t-Test

\begin{tabular}{llccccc}
\hline & & \multicolumn{2}{c}{$\begin{array}{c}\text { Unstandardized } \\
\text { Coefficients }\end{array}$} & $\begin{array}{c}\text { Standardized } \\
\text { Coefficients }\end{array}$ & & \\
\cline { 3 - 5 } Model & & $\mathrm{B}$ & Std. Error & Beta & $\mathrm{t}$ & Sig. \\
\hline \multirow{2}{*}{1} & (Constant) & .011 & .008 & & -1.263 & .207 \\
& Market to Book Assets Ratio & .018 & .001 & .558 & 24.892 & .000 \\
& DAR & .105 & .016 & .142 & 6.396 & .000 \\
& Dividend Yield & .397 & .048 & .179 & 8.345 & .000 \\
\hline
\end{tabular}

Table 6. Coefficient of Determination

\begin{tabular}{lrrr}
\hline \multicolumn{1}{c}{ Variable } & $\begin{array}{c}\text { Standardized } \\
\text { Coefficients Beta }\end{array}$ & Zero-Order & $\begin{array}{c}\text { Partial R } \\
\text { Square }\end{array}$ \\
\hline Market to Book Assets Ratio & .558 & .618 & 0.345 \\
DAR & .142 & .299 & 0.043 \\
Dividend Yield & .179 & .238 & 0.043 \\
& R Square & 0.430 \\
& Adjusted R square & 0.428 \\
& Std. Error of the Estimate & 0.13726 \\
& $\mathrm{R}$ & 0.656 \\
\hline
\end{tabular}

Scatterplot

Dependent Variable: BEP

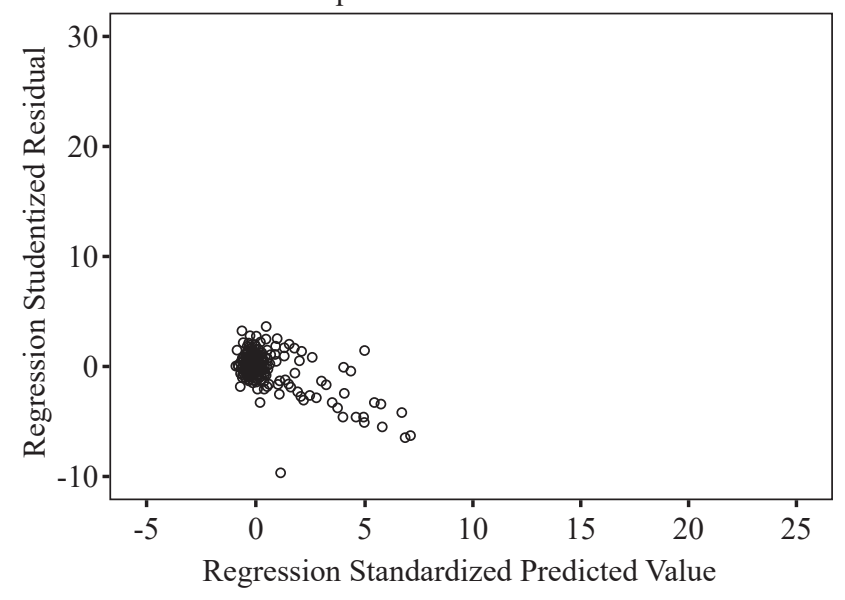

Figure 1. Test of Heteroscedasticity 